\title{
IMPLEMENTASI MODEL WATERFALL DALAM SISTEM INFORMASI AKUNTANSI PIUTANG JASA PENYEWAAN KENDARAAN PADA PT. TRICIPTA SWADAYA KARAWANG
}

\author{
${ }^{1}$ Eva Nurfitriana ${ }^{2}$ Widya Apriliah ${ }^{3}$ Herlina Ferliyanti ${ }^{4}$ Hasan Basri ${ }^{5}$ Ratnawati \\ Email: 1evanurfitriana14@gmail.com, ${ }^{2}$ widyaapriliah64@gmail.com, ${ }^{3}$ herlina.hit@bsi.ac.id \\ ${ }^{4}$ hasan.hhi@bsi.ac.id, ${ }^{5}$ ratnawati.rtx@bsi.ac.id
}

\begin{abstract}
Abstrak
Sekarang ini, sistem informasi yang berteknologi tinggi dapat menghasilkan peranan yang sangat penting dalam berbagai kemajuan perkembangan teknologi yang maju begitu cepat dari waktu ke waktu. Sistem informasi yang telah terkomputerisasi tentu akan memberikan kinerja yang lebih efisien dibandingkan dengan sistem yang dalam penerpannya masih menggunakan cara manual. PT. Tricipta Swadaya Karawang adalah perusahaan yang bergerak dibidang penyewaan barang dan jasa, salah satunya adalah jasa penyewaan kendaraan yaitu truk. Proses pengolahan data transaksi dalam kegiatan bisnis perusahaan ini masih menggunakan proses pengolahan data yang manual belum memiliki sebuah sistem informasi yang terintegrasi dengan database dimulai dari pendataan pemesanan mobil-mobilnya hingga dalam proses pelaporan pengolahan data nya, yang mana sistem saat ini yang masih menggunakan sistem konvensional ditemukan kendala-kendala seperti kesalahan dalam pencatatan dan perhitungan sampai pada proses pembuatan laporan transaksi nya yang masih belum efektif, efisien dan rapi. Berdasarkan kondisi tersebut maka perlu diusulkan dan dirancang sebuah sistem informasi dalam proses mengolah data transaksi pemesanan mobil yang penulis rancang dan usulkan sebagai solusi dari kendala yang dihadapi pada sistem yang berjalan pada perusahaan ini dalam perancangan program pemesanan ini penulis menggunakan tools visual basic dalam perancangan user interface program dan metode waterfall sebagai metode pengembangan softwarenya, serta dengan adanya sistem yang telah terkomputerisasi tentunya pemesanan kendaraan tersebut lebih efektif dan efisiensi dalam menunjang kinerja yang jauh lebih baik pada PT. Tricipta Swadaya Karawang ini.

Kata Kunci: Jasa, Penyewaan, Kendaraan, Waterfall
\end{abstract}

\section{Abstract}

Todays, system of information have a high technology to produce is the most important rule in our life, the development technology has been advancing in it faster time by time. System of information has computerized, certainly it would give the better of performance ever it's like more effectively and faster than manual system what they're using. PT. Tricipta Swadaya Karawang is one of company who engaged in rent of goods and services, and which one of the services is vehicle rental service that is truck. The processing of transaction data in company business activities still use manual data processing that does not yet have an integrated information system from the database starting from the data collection of the cars to the data processing reporting process, which is the current system that still use conventional systems found obstacles such as errors in recording and calculation up to the process of making transaction reports that are still not effective, efficient and tidy. Based on these conditions it is necessary to propose and design an information system in the process of processing car booking transaction data that the author designed and proposed as a solution to the constraints faced by the system that runs on this company in designing this ordering program the author uses visual basic tools in designing the user interface the waterfall program and method as the software development method and with the existence of a computerized system of course ordering the vehicle is more effective and efficient in supporting a much better performance at PT. Tricipta Swadaya Karawang.

Keywords: Services, Rent, Vehicle, Waterfall 


\section{Pendahuluan}

Teknologi komputerisasi sangat memberikan kemudahan kepada kegiatan dan kinerja para penggunanya yang tak jarang dapat memberikan kenaikan tingkat efektifitas dan efisiensi di dalam melakukan pekerjaan pengunanya. Sistem yang telah terkompuerisasi dengan baik akan menghasilkan informasi jauh lebih baik juga dari sistem yang manual.

Tanpa disadari waktu demi waktu komputer tidak hanya dipandang sebagai benda elektronik yang hanya bisa mengetik, menampilkan gambar, mengeluarkan audio bahkan menyimpan data-data, dimasa sekarang sudah banyak terciptanya sistem-sistem pengolahan informasi yang terkomputerisasi. Seperti halnya saat ini sistem yang terkomputerisasi telah memasuki berbagai macam dunia usaha.

PT. Tricipta Swadaya Karawang adalah perusahaan yang bergerak dibidang penyewaan barang dan jasa, salah satunya adalah jasa penyewaan truk. Permasalahan yang terjadi di PT. Tricipta Swadaya Karawang adalah pengolahan dan pencatatan data transaksi penyewaan, pembayaran transaksi masih belum tersistematis dan masih memungkinkan terjadinya kesalahan pencatatan transaksi yang mengakibatkan pekerjaan menjadi terhambat dan tidak efektif. Untuk meningkatkan kinerja PT. Tricipta Swadaya Karawang perlu diterapkan suatu teknik manajemen dalam mengelola data-data transaksi sehingga menghasilkan informasi keuangan yang bermanfaat bagi perusahaan.

Berdasarkan adanya kendala-kendala tersebut, melalui penelitian ini bertujuan untuk mendapatkan solusi yang dapat diterapkan pada PT. Tricipta Swadaya Karawang dalam pengolahan data transaksi penyewaan kendaraannya dengan merancang sebuah program penyewaan berupa sistem informasi jasa penyewaan kendaraan berbasis dekstop.

\section{Tinjauan Pustaka}

\section{Pengertian Sistem Informasi}

Menurut Fridayanthie dan Charter (2016:65), mendefinisikan "sistem informasi adalah kegiatan dari prosedur yang di organisasikan yang digunakan untuk menyediakan informasi pengambilan keputusan dan pengendalian didalam organisasi”.

\section{Pengertian Akuntansi}

Menurut Mulyadi dalam Apriliah, Subekti, dan Haryati (2019:35) mendefinisikan bahwa "akuntansi merupakan kegiatan organisasi formulir, mencatat data keuangan untuk menghasilkan informasi keuangan yang dibutuhkan untuk memudahkan manajemen dalam pengolahan data keuangan perusahan".

\section{Pengertian Sistem Informasi Akuntansi}

Menurut Fauziah dan Laraswati (2015:248), "Sistem Informasi Akuntansi adalah sekumpulan susunan formulir catatan, seperangkat peralatan termasuk komputer, tenaga pelaksana serta laporan yang di buat untuk mentransformasikan data keuangan menjadi informasi yang dibutuhkan manajemen".

\section{Pengertian Bahasa Pemrograman Java}

Menurut enterprise (2015:19), mendefinisikan bahwa bahasa pemrograman "Java dapat didefinisikan sebagai sebuah kumpulan objek-objek yang saling berkomunikasi dengan cara memanggil methodmethod yang dimiliki masing-masing objek".

\section{Pengertian Model Waterfall}

Menurut Sholikhah, Sairan, dan Syamsiah (2017:47) menjelaskan bahwa, "Waterfall merupakan model klasik yang memiliki sifat berurut dalam merancang software".

\section{Pengertian Entity Relationship Diagram}

Menurut Sukamto dan Shalahudin dalam Apriliah, dkk (2018:30) menyimpulkan bahwa "entity relationship diagram (ERD) adalah sebuah diagram yang digunakan untuk merancang hubungan antar tabel-tabel dalam basis data".

\section{Pengertian Logical Record Structure}

Menurut Nugraha dan Octasia dalam Apriliah, dkk (2018:30) menyimpulkan bahwa "LRS merupakan representasi dari struktur 
record-record pada tabel-tabel yang terbentuk berdasarkan hasil relasi antar entitas yang terdapat pada diagram E-R".

\section{Pengertian Unified Modelling Languange (UML)}

Menurut Sukamto dan Shalahuddin (2018:133) mendefinisikan bahwa UML merupakan sebuah standar bahasa yang digunakan untuk menganalisis dan merancang serta menggambarkan arsitektur program dalam pemrograman object oriented.

\section{Pengertian Activity Diagram}

Menurut Tohari dalam Tabrani dan Aghniya (2019:45) mendefinisikan bahwa, "activity diagram memodelkan workflow proses bisnis dan urutan aktifitas dalam sebuah proses. Diagram ini sangat mirip dengan flowchart karena memodelkan workflow dari suatu aktifitas lainnya atau dari aktifitas ke status".

\section{Pengertian UseCase Diagram}

Menurut Tohari dalam Tabrani dan Aghniya (2019:46) menyimpulkan bahwa, "use case adalah rangkaian atau uraian sekelompok yang saling terkait dan membentuk sistem secara teratur yang dilakukan atau diawasi oleh sebuah aktor".

\section{Pengertian Piutang}

Menurut Fitriyana dan Susianto, (2018:34) mendefinisikan piutang "merupakan salah satu aktiva lancar yang penting dalam aktivitas ekonomi suatu perusahaan karena merupakan aktiva lancar yang paling besar setelah kas".

Menurut Fitriyana dan Susianto (2018:34), "adanya piutang berasal dari adanya transaksi penjualan barang atau jasa secara kredit".

\section{Metode Penelitian}

\section{Metode Pengumpulan Data}

Metode pengumpulan data dalam penelitian ini yang digunakan yaitu dengan menggunakan metode observasi, metode wawancara dan metode studi pustaka.

\section{Metode Pengembangan Perangkat Lunak}

Pembuatan Sistem Informasi penelitian ini metode yang digunakan dalam pengembangan perangkat lunak menggunakan model waterfall dimana model ini menurut Imroatus, dkk dalam Apriliah, dkk (2018:30) merupakan model klasik yang bersifat sistematis dalam pembuatan perangkat lunak, yang terbagi atas lima tahap, yaitu:

a. Analisa Kebutuhan Sistem

Dalam tahap awal pengembangan perangkat lunak adalah dengan analisa kebutuhan sistem yang dibutuhkan dalam mengembangkan program yang akan dibuat dan sesuai dengan kebutuhan sistem pengolahan transaksi penyewaan terdiri dari menu-menu yang diperlukan antara lain: menu login admin, menu utama, menu master terdiri dari submenu pengguna, submenu perusahaan, submenu kendaraan, submenu trayek dan data akun. Menu transaksi terdiri dari submenu penyewaan, submenu surat jalan, submenupenagihan, submenu pembayaran dan submenu jurnal.

b. Desain

Tahap kedua sesuai dengan model waterfall yang digunakan dalam pengembangan perangkat lunak adalah proses proses desain database maupun desain sistem informasi yang akan dibangun. Adapun tools yang digunakan adalah Entity Relationship Diagram (ERD) dan Logical Record Structure (LRS) yang digunakan untuk desain database yang akan dibangun dan diagram UML tediri dari use case Diagram dan Activity Diagram yang dipergunakan untuk desain sistem informasi yang akan dibuat.

c. Pengkodean

Adapun tahap ketiga dalam metode pengembangan perangkat lunak selanjutnya dilakukan tahap pengkodean dimana desain yang telah dibuat dan dirancang pada tahap sebelumnya ditranslasikan kedalam bentuk aplikasi sistem informasi. Aplikasi sistem informasi yang dibangun dalam penelitian ini menggunakan Bahasa pemrograman java dengan MySQL sebagai databasenya.

d. Pengujian

Tahap selanjutnya setelah analisa kebutuhan 
sistem, tahap desain dan pengkodean dalam pengembangan perangkat lunak adalah dalam proses ini dilakukan tahap pengujian. Dimana dalam tahap pengujian ini dilakukan dengan cara mendeskripsikan hasil dengan menggunakan metode pengujian blackbox testing yang digunakan untuk meminimalisir terjadinya kesalahan dan menilai apakah aplikasi yang telah dibuat sudah sesuai kebutuhan user dan sesuai dengan rancangan sebelum diimplementasikan.

\section{Hasil dan Pembahasan}

1. Analisa Kebutuhan

Pada tahap analisa kebutuhan ini, merupakan tahapan yang dilakukan dengan menganalisa kebutuhan dengan mengidentifikasi kebutuhan yang diperoleh berdasarkan kebutuhan pengguna. Adapun kebutuhan sistem dalam sistem informasi yang akan dibuat ini terbagi menjadi 2 hak akses pengguna yang dapat menggunakan sistem informasi ini sebagai berikut:

A. Halaman Admin

A1. Admin login

A2. Admin dapat mengelola Menu Master

A2.1. Admin mengelola menu master pengguna.

A2.2. Admin mengelola menu master perusahaan.

A2.3. Admin mengelola menu master kendaraan.

A2.4. Admin mengelola menu master trayek.

A2.5. Admin mengelola menu master akun.

A2.6. Admin mengelola menu master supir

A3. Admin dapat mengelola Menu Transaksi

A3.1. Admin dapat mengelola menu transaksi penyewaan.

A3.2. Admin dapat mengelola menu transaksi surat jalan.

A3.3. Admin dapat mengelola menu transaksi tagihan

A3.4. Admin dapat mengelola menu transaksi pembayaran.

A3.5. Admin dapat mengelola menu transaksi jurnal.

\section{A4. Admin Logout}

B. Halaman Pemilik

B1. Pemilik login

B2. Pemilik dapat mengakses Menu Utama

B2.1. Pemilik mengakses Menu Laporan

B3. Pemilik dapat mengelola Menu Laporan

B4. Pemilik Logout

2. Desain

a. Use Case Halaman Admin

Berikut adalah diagram usecase untuk hak akses admin.

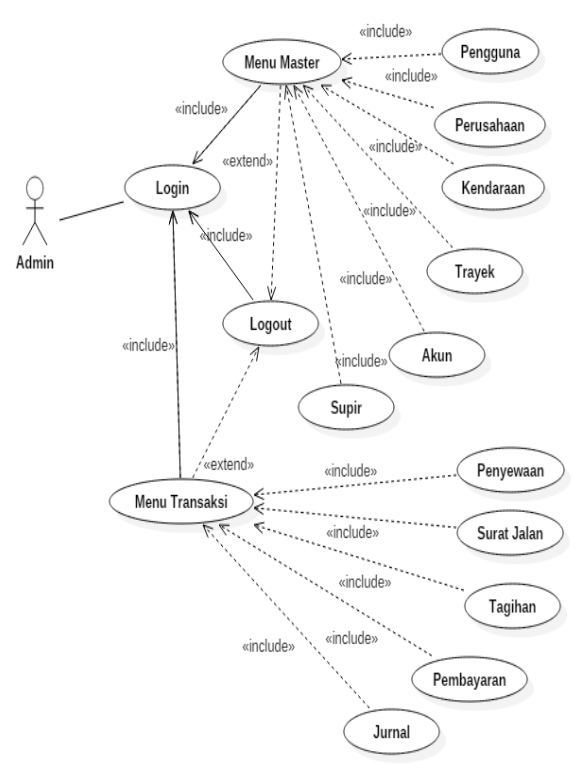

Gambar 1. Use Case Admin

Sumber: Hasil Penelitian (2020) 
b. Use Case Halaman Pemilik Berikut adalah diagram use case untuk hak akses pemilik

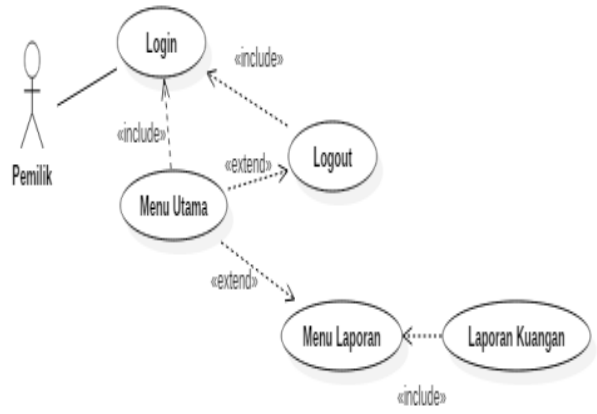

Gambar 2. Use Case Menu pemilik Sumber: Hasil Penelitian (2020)

c. Activity Diagram Menu Transaksi Penyewaan

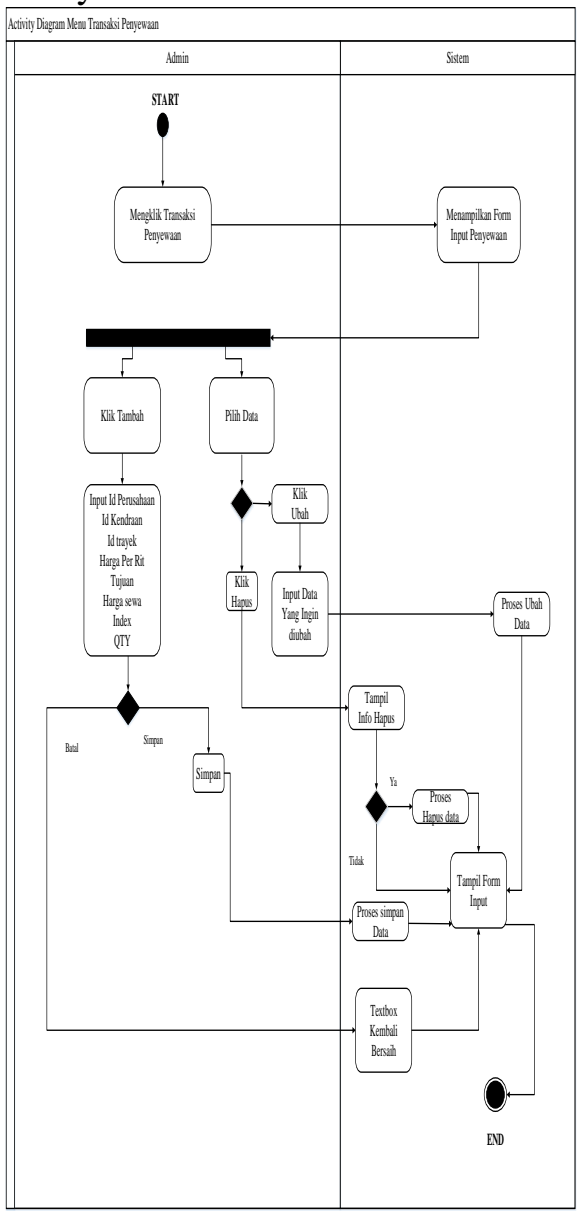

Gambar 3. Activity Diagram Menu Transaksi Simpan Dana

Sumber: Hasil Penelitian (2020) d. Activity Diagram Menu Transaksi Penagihan

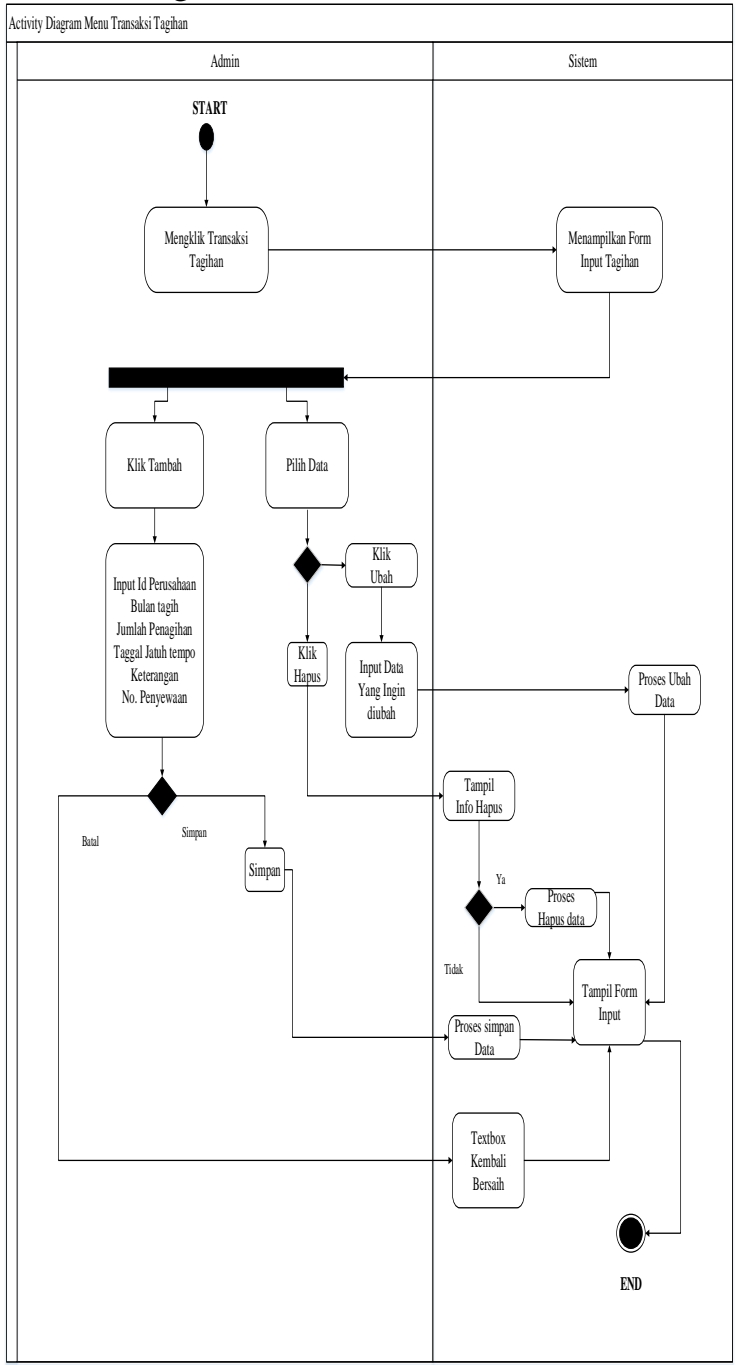

Gambar 4. Activity Diagram Menu Transaksi Peminjaman Dana

Sumber: Hasil Penelitian (2020)

\section{e. Entity Relationship Diagram}

Berikut adalah rancangan database dari sistem informasi piutang jasa penyewaan dalam bentuk diagram ERD. 


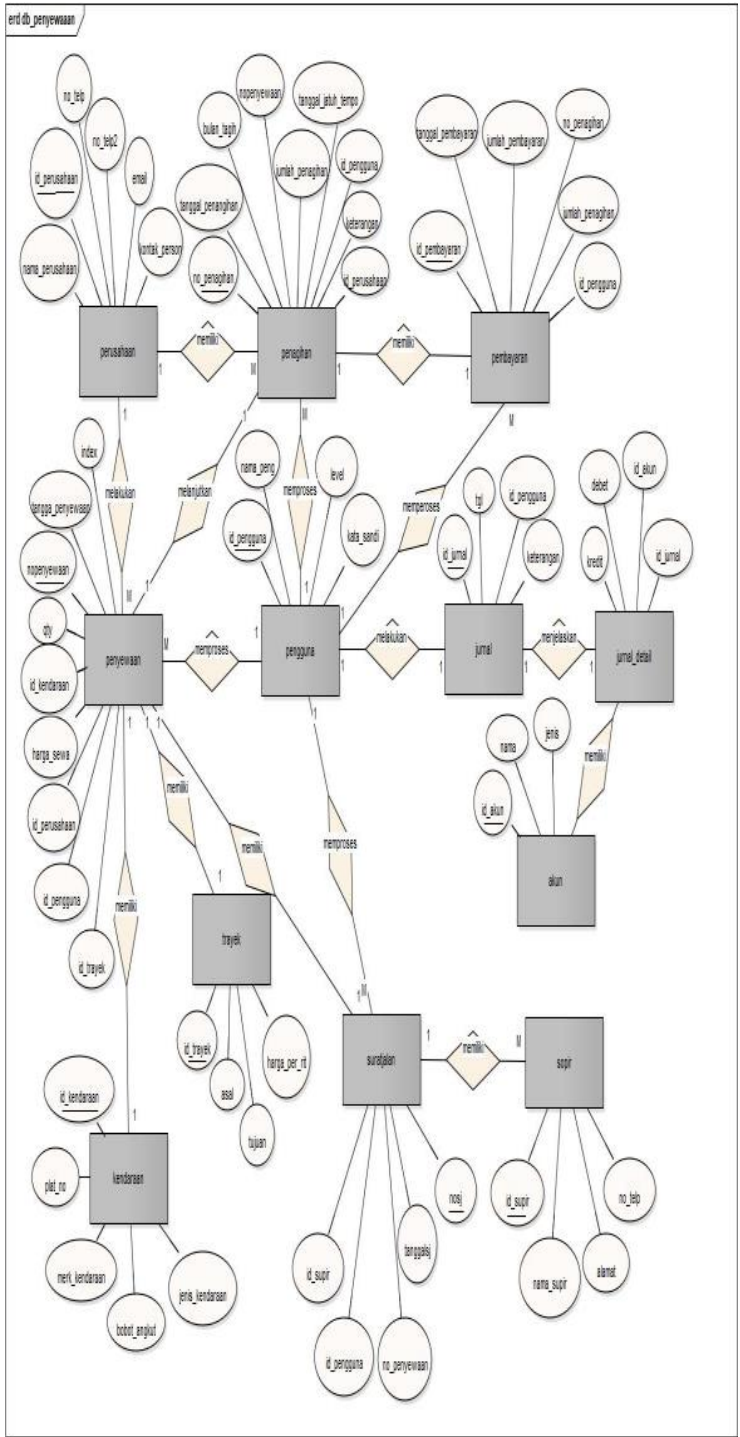

Gambar 5. Entity Relationship Diagram

Sumber: Hasil Penelitian (2020)

\section{f. Logical Record Structure}

Berikut adalah rancangan database dari sistem informasi piutang jasa penyewaan dalam bentuk diagram LRS.

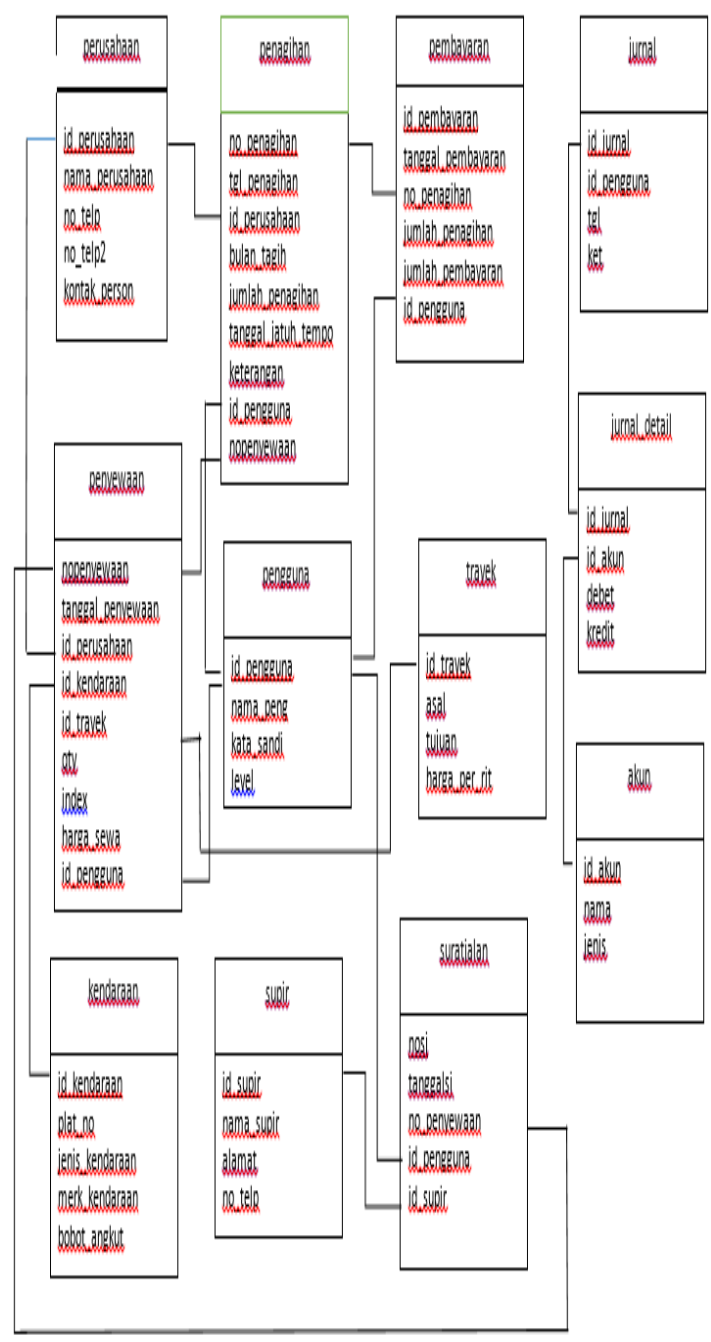

Gambar 6. Logical Record Structure Sumber: Hasil Penelitian (2020)

\section{g. Spesifikasi File}

Berikut adalah spesifikasi file dari tabel dalam database dari sistem informasi piutang jasa penyewaan.

Tabel 1. Spesifikasi File Table Penyewaan

\begin{tabular}{|c|l|c|c|c|}
\hline Elemen data & \multicolumn{1}{|c|}{ Akronim } & Type Data & Size & Ket \\
\hline No Penvewanan & no_penyewaan & Char & 4 & Primary Key \\
\hline Tanggal penyewaan & tanggal_penyewaan & Date & & \\
\hline Id Perusahaan & id_perusahaan & Char & 4 & Foreign Key \\
\hline Id Kendaraan & id_kendaraan & Char & 4 & Foreign Key \\
\hline Id Trayek & id_trayek & Char & 4 & Foreign Key \\
\hline QTY & qty & Int & 11 & \\
\hline Index & index & Varchar & 10 & \\
\hline Harga Sewa & harga_sewa & Double & & \\
\hline
\end{tabular}




\section{h. Spesifikasi File}

Berikut adalah spesifikasi file dari tabel dalam database dari sistem informasi piutang jasa penyewaan.

Tabel 2. Spesifikasi File Table Penagihan

\begin{tabular}{|c|c|c|c|c|}
\hline Elemen data & Akronim & Type Data & Size & Ket \\
\hline No Penaghinan & 200 penagihan & Char & 4 & Primary $\mathrm{Ke}$ ? \\
\hline Tangel Peragihan & tanggal_pengihinan & Varchar & 20 & Forerien $\mathrm{Key}$ \\
\hline Bulab Tagih & bullan_tagih & Char & 4 & \\
\hline Jumlah Penagihan & jumlah_penaghan & Double & & \\
\hline Toll Inhih Tempo & tangegl_jinin_tempo & Varchar & 20 & \\
\hline Keterangan & keterangan & Varchar & 25 & \\
\hline Id Pengyuma & id penegrama & Barchar & 20 & Foretign $\mathrm{Key}$ \\
\hline Id Perusuhanan & id pensushanan & Char & 4 & Fortien $\mathrm{Keg}$ \\
\hline No Penyeuman & \begin{tabular}{|l|l|l} 
ncpetyenelam \\
\end{tabular} & Varchar & 10 & \\
\hline
\end{tabular}

\section{Implementasi}

\section{Form Login}

Berikut tampilan form login dari progam, jika admin atau pemilik akan mengakses program langkah awal untuk akses adalah dengan mengisi kode pengguna dan password yang valid pada masing-masing textbox.

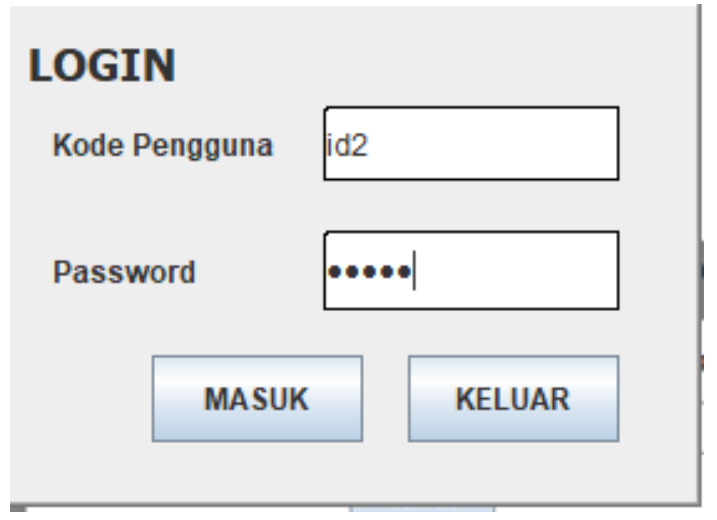

\section{Gambar 7. Form Login}

Sumber: Hasil Penelitian (2020)

2. Form Menu Utama Admin

Dalam form menu utama dalam program ini pengguna dapat memilih menu-menu yang terdapat dalam form menu utama ini diantaranya menu master data yang terdiri dari submenu pengguna, perusahaan, kendaraan, trayek, supir, dan akun serta Menu transaksi yang terdiri dari sub menu penyewaan, surat jalan, penagihan, pembayaran dan jurnal, lalu Menu Logout untuk keluar dari Sistem.

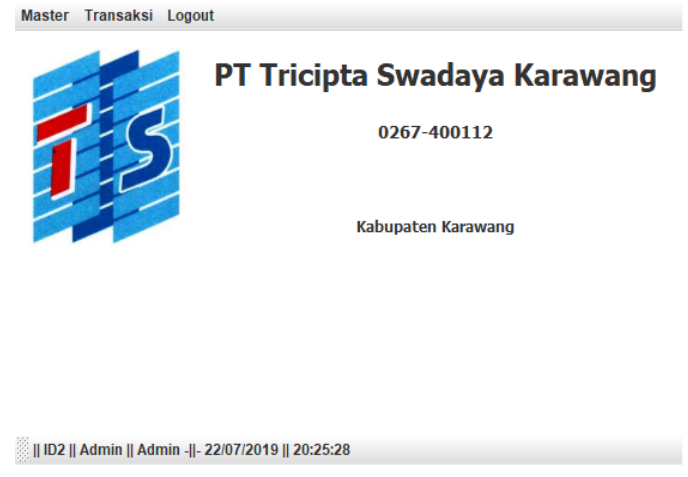

Gambar 8. Form Menu Utama

Sumber: Hasil Penelitian (2020)

3. Form Input Data Kendaraan

Pada menu ini, admin dapat menambah data kendaraan, menyimpan ataupun membatalkan input data, serta admin dapat mengubah dan menghapus data kendaraan.

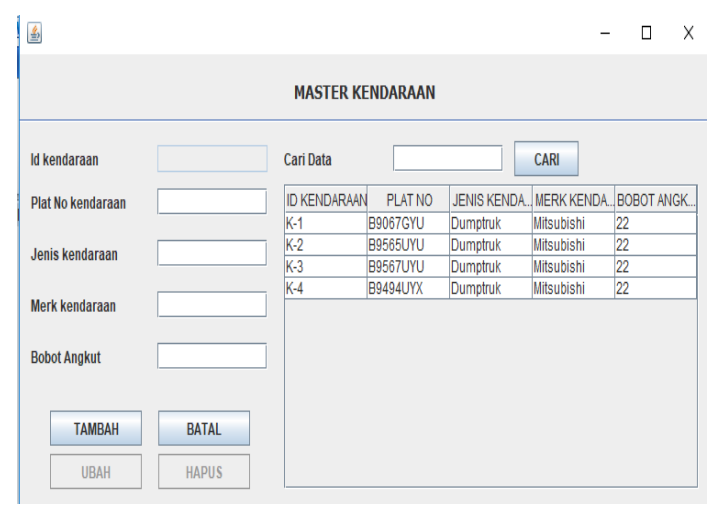

Gambar 9. Form Input Data Kendaraan Sumber: Hasil Penelitian (2020)

\section{Form Input Data Trayek}

Pada menu ini admin dapat menambah data trayek, menyimpan ataupun membatalkan, serta admin dapat mengubah dan menghapus data trayek.

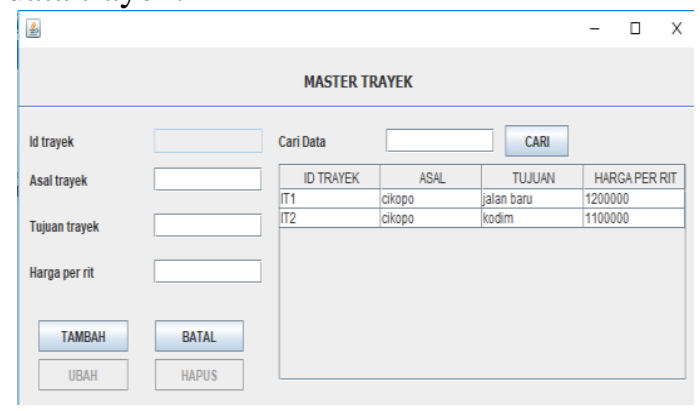

Gambar 10. Form Input Data Trayek

Sumber: Hasil Penelitian (2020) 
5. Form Input Data Transaksi Penyewaan

Dalam form submenu transaksi penyewaan ini admin dapat menambah data baru, menyimpan data baru dan membatalkan transaksi penyewaan.

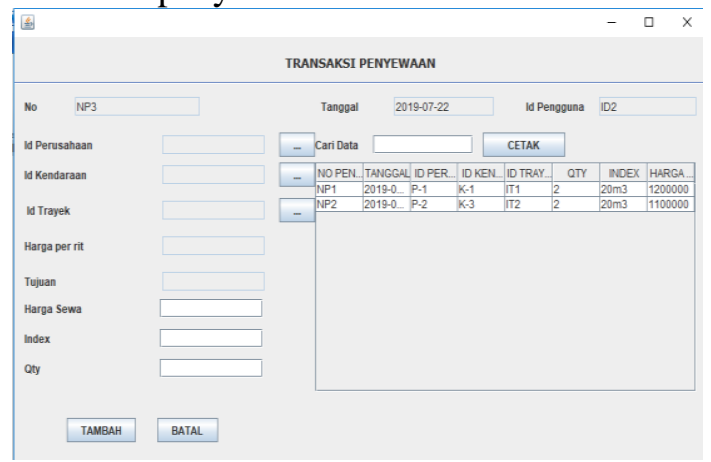

Gambar 11. Form Input Data Penyewaan

Sumber: Hasil Penelitian (2020)

6. Form Input Data Surat Jalan

Pada menu ini dapat digunakan admin untuk membuat surat jalan dengan menu yang dapat digunakan anatara lain menambah, menyimpan, membatalkan data pembuatan surat jalan berdasarkan id penyewaan.

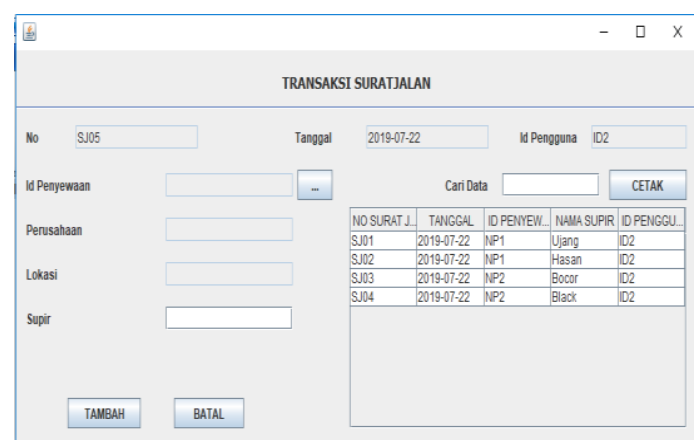

Gambar 12. Form Input Data Surat Jalan

Sumber: Hasil Penelitian (2020)

7. Form Input Data Penagihan

Dalam form menu ini admin dapat melakukan pengolahan data penagihan atas transaksi penyewaan kendaraan adapun menu yang terdapat dalam menu ini anatar lain admin dapat menambah, menyimpan, membatalkan dan pencarian data.

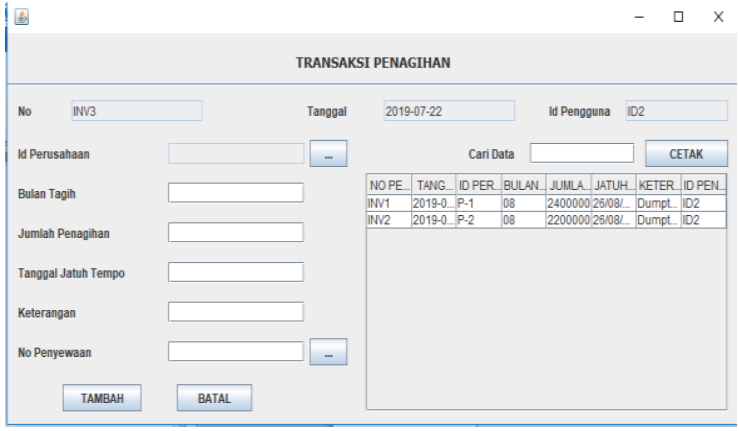

Sumber: Hasil Penelitian (2020)

Gambar 13. Form Input Data Penagihan

8. Form Input Data Pembayaran

Pada form menu pembayaran ini admin dapat mengelola data pembayaran atas transaksi pembayaran piutang penyewaan kendaraan berdasarkan no penagihan.

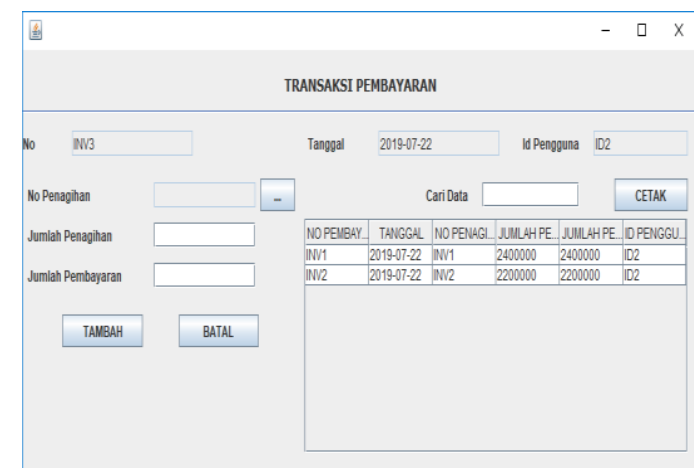

Gambar 14. Form Input Data Pembayaran Sumber: Hasil Penelitian (2020)

\section{Form Jurnal}

Pada form menu jurnal ini admin dapat mengelola dan mencatat data transaksi untuk dibuatkan pencatatan transaksi dalam bentuk jurnal.

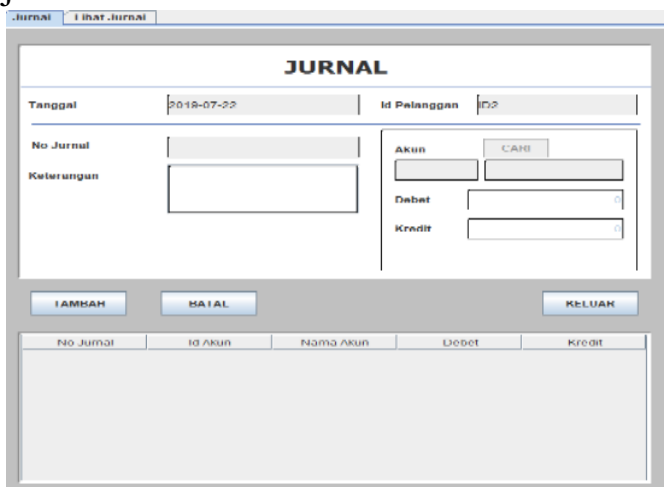

Gambar 15. Form Input Jurnal

Sumber: Hasil Penelitian (2020) 
10.Menu Laporan

Pada menu laporan ini, yang dapat mengakses adalah hanya user dengan hak akses level nya sebagai pemilik, dimana dalam menu ini berfungsi untuk melihat, mencetak dan menyimpan laporan keuangan berdasarkan tanggal, bulan ataupun tahun yang diinginkan.

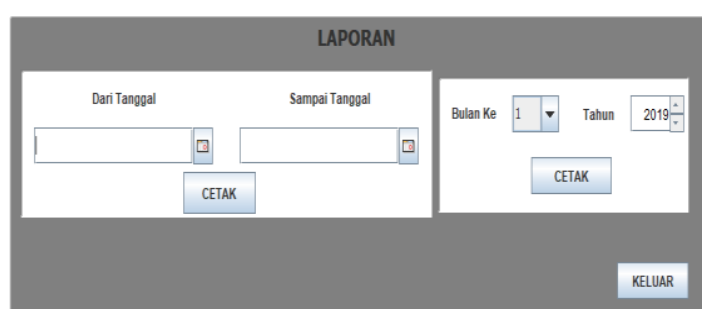

Gambar 16. Menu Laporan

Sumber: Hasil Penelitian (2020)

\section{Testing}

Pada tahap pengujian ini penulis menggunakan pendekatan pengujian validasi dengan menggunakan Black Box Testing (pengujian kotak hitam) yang digunakan untuk menguji kesiapan dan kesesuaian sistem informasi yang dibangun sebelum diimplementasikan dengan berfokus pada persyaratan fungsional dari sistem yang dibangun.

Tabel 1. Blackbox Testing Menu Login

\begin{tabular}{|c|c|c|c|c|c|}
\hline No & $\begin{array}{l}\text { Skenario } \\
\text { Pengujian }\end{array}$ & $\begin{array}{l}\text { Test } \\
\text { Case }\end{array}$ & $\begin{array}{l}\text { Hasil Yang } \\
\text { Diharapkan }\end{array}$ & $\begin{array}{c}\text { Hasil } \\
\text { Pengujia } \\
\text { n }\end{array}$ & $\begin{array}{c}\text { Kesimpu } \\
\text { lan }\end{array}$ \\
\hline 1 & $\begin{array}{l}\text { Mengosongkan } \\
\text { semua isian data } \\
\text { login, kemudian } \\
\text { langsung klik } \\
\text { tombol 'Login' }\end{array}$ & $\begin{array}{l}\text { Kode } \\
\text { Penggun } \\
\text { a: } \\
\text { (Kosong } \\
\text { ) } \\
\text { Passwor } \\
d: \\
\text { (Kosong } \\
\text { ) }\end{array}$ & $\begin{array}{l}\text { Sistem akan } \\
\text { menolak akses } \\
\text { login dan } \\
\text { menampilkan } \\
\text { pesan "Data tidak } \\
\text { ditemukan !!" }\end{array}$ & $\begin{array}{c}\text { Sesuai } \\
\text { Harapan }\end{array}$ & Valid \\
\hline 2 & $\begin{array}{l}\text { Hanya mengisi } \\
\text { data kode } \\
\text { Pengguna, } \\
\text { mengosongkan } \\
\text { data password, } \\
\text { kemudian } \\
\text { langsung klik } \\
\text { tombol 'Login' }\end{array}$ & $\begin{array}{l}\text { Kode } \\
\text { Penggun } \\
\text { a: U001 } \\
\text { Passwor } \\
d: \\
\text { (Kosong } \\
\text { ) }\end{array}$ & $\begin{array}{l}\text { Sistem akan } \\
\text { menolak akses } \\
\text { login dan } \\
\text { menampilkan } \\
\text { pesan "Data tidak } \\
\text { ditemukan!!" }\end{array}$ & $\begin{array}{c}\text { Sesuai } \\
\text { Harapan }\end{array}$ & Valid \\
\hline 3 & $\begin{array}{l}\text { Hanya mengisi } \\
\text { data password } \\
\text { dan } \\
\text { mengosongkan } \\
\text { kode Pengguna, } \\
\text { kemudian } \\
\text { langsung klik } \\
\text { tombol 'Login' }\end{array}$ & $\begin{array}{l}\text { Passwor } \\
d: \text { Ba03 } \\
\text { Kode } \\
\text { Penggun } \\
a: \\
\text { (Kosong } \\
\text { ) }\end{array}$ & $\begin{array}{l}\text { Sistem akan } \\
\text { menolak akses } \\
\text { login dan } \\
\text { menampilkan } \\
\text { pesan "Data tidak } \\
\text { ditemukan !!" }\end{array}$ & $\begin{array}{c}\text { Sesuai } \\
\text { Harapan }\end{array}$ & Valid \\
\hline 4 & $\begin{array}{l}\text { Menginputkan } \\
\text { dengan kondisi } \\
\text { salah satu data } \\
\text { benar dan salah } \\
\text { satu lagi salah, } \\
\text { kemudian klik } \\
\text { tombol 'Login' }\end{array}$ & $\begin{array}{l}\text { Kode } \\
\text { Penggun } \\
\text { a: U001 } \\
\text { (Benar) } \\
\text { Passwor } \\
d: \\
\text { Asd01 } \\
\text { (Salah) }\end{array}$ & $\begin{array}{l}\text { Sistem akan } \\
\text { menolak akses } \\
\text { login dan } \\
\text { menampilkan } \\
\text { pesan "Data tidak } \\
\text { ditemukan!!" }\end{array}$ & $\begin{array}{c}\text { Sesuai } \\
\text { Harapan }\end{array}$ & Valid \\
\hline
\end{tabular}

\section{Kesimpulan dan Saran}

\section{Kesimpulan}

Berdasarkan pembahasan sebelumnya mengenai perancangan sistem informasi akuntansi piutang jasa penyewaan truk Pada PT. Tricipta Swadaya Karawang dapat disimpulkan bahwa dengan mengusulkan, merancang dan menerapkan sistem informasi yang telah dibuat jelas sekali terlihat dapat mengatasi kendala yang dihadapi dalam mengolah data sehingga dalam proses mengolah, melakukan pencarian, penyimpanan data transaksi piutang atas jasa penyewaan kendaraan hingga menghasilkan suatu laporan transaksi menjadi lebih mudah, cepat, terorganisir dengan baik dan rapi karena sudah tersimpan dalam bentuk file pada sistem informasi.

\section{Saran}

Adapun saran yang dapat penulis berikan guna perbaikan dan pengembangan sistem informasi agar menjadi semakin lebih baik sesuai dengan kebutuhan sistem dimasa mendatang sebagai berikut:

1. Konsisten untuk mengoptimalkan fungsi backup untuk kemanan data transaksi secara berkala.

2. Perlunya pelatihan terhadap user yang akan menggunakan sistem informasi ini agar user yang akan menggunakan sistem informasi ini memahami fungsi-fungsi dari menu yang ada dalam sistem informasi dan meminimalisir kekeliruan dalam pengoperasian sistem informasi.

3. Mengadakan evaluasi terhadap sistem informasi pada periode tertentu guna mengetahui apabila ditemukan kelemahan atau adanya penambahan kebutuhan dalam sistem informasi dimasa mendatang.

\section{Daftar Pustaka}

Apriliah, W., R. Ningsih, N. Ariyanti, dan T. Haryati. 2018. "Rancang Bangun Sistem Informasi Penerimaan Dan Pengeluaran Kas Pada PT. Rhadogel Gums Internasional Bekasi." INKOFAR Volume (1)(2):29-39. 
Apriliah, Widya, Neni Subekti, dan Tri Haryati. 2019. "Penerapan Model Waterfall Dalam Perancangan Aplikasi Sistem Informasi Simpan Pinjam Pada Koperasi PT. Chiyoda Integre Indonesia Karawang." Jurnal Interkom 14(2):34-42.

Enterprise, J. 2015. Mengenal java dan database dengan netbeans. PT. Elex Media Komputindo. Jakarta.

Fauziah, Mar'atul dan Dewi Laraswati. 2015. "Perancangan Sistem Informasi Akuntansi Simpan Pinjam Pada Koperasi Pasar Induk Kramat Jati Jakarta." Sistem Informasi STMIK Antar Bangsa IV:24755.

Fitriyana, Iis dan Didi Susianto. 2018. "Aplikasi Akuntansi Piutang Jasa Service Pada PT. AUX Indonesia Bandar Lampung." 1(1):32-49.

Sholikhah, Imroatus, Mahmud Sairan, dan Nurfia Oktaviani Syamsiah. 2017. "Aplikasi Pembelian Dan Penjualan Barang Dagang Pada Cv Gemilang Muliatama Cikarang.” Jurnal Teknik Komputer Amik BSI Volume II (no1):1623.

Sukamto, dan Shalahudin. (2018). Rekayasa Perangkat Lunak. Bandung: Informatika

Tabrani, Muhamad dan Insan Rezqy Aghniya. 2019. "Implementasi Metode Waterfall Pada Program Simpan Pinjam Koperasi Subur Jaya Mandiri Subang." Jurnal Interkom 14(1):44-53. 